crossbred samples. Boars and females were mated on a within company basis, the test aiming to use 8 boars, and at least 24 females per company. Two litters per female were used, and the aim was to assess the reproductive traits of the hybrid pigs from results of 48 litters. Pigs for feeding trials were allocated to one of these treatments; two feeding systems were used, ad-lib. and restricted, and three slaughter weights, pork, bacon and heavy manufacturing pigs. Carcass evaluation involved standard moasurements ; about one-third of the carcases had one side fully separated, and the remainder had a sample joint separated.

Few disease problems were experienced, although breeding pigs from many sources were mixed. Actual levels of performance were good. The results show fairly wide differences in levels of performance between the various samples for the characters considered. With only 48 litters per sample, few statistically significant differences in reproductive performance could be demonstrated, but in the feeding evaluation there were a large number of significant differences. Overall, the performance of British company and purebred pigs is highly satisfactory.

\title{
RESUlTS OF THE GERMAN FEDERAL CROSSBREEDING PROGRAMME IN PIGS
}

\section{P. GLodeK. - Institut $f$. Tierzucht und Haustiergenetik der Universtität Göttingen, BRD.}

Without considering litter performance the best hybrid exceeded commercial DL-control by DM I6.59 per pig under good and by 22.03 per pig under poor management conditions. The mean of Io tested crosses was about 10. - DM under good and even over 20. - DM per pig under poor conditions superior to the commercial control. It is interesting to note that the DL-PedigreePigs received the best carcass grades on the market but in overall profit per pig they suffered because they had 4 -times as many losses during fattening as hybrid pigs. Under good management conditions purebred pigs still had reasonable losses but with poor management losses during fattening exceedet Io p. Ioo so that there profitable production of slaughter pigs was impossible with pure breds.

\section{CURREN'T EXPERIMENTS ON PIG CROSSBREEDING IN POLAND}

\section{Z. Piasek, S. Plonka.}

In 3 field experiments reproductive performance, fattening results and carcass traits of purebred Polish Large White (PLW) Polish Landrace ( $P L)$ and following combinations of crossbred pigs has been compared :

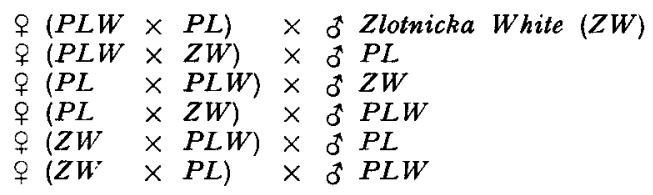

Small differences in performance of compared groups of pigs has been stated. Only $q$ ( $P L W \times$ $\left.Z W^{*}\right) \times$ o $P L$ crossbred combination seems to be superior to purebred $P L W$ and $P L$ groups in respect to reproductive and fattening characteristics.

\section{THE RELATIONSHIP BETWEEN HETEROSIS AND HETEROZYGOSITY IN REPRODUCTIVE TRAITS IN MICE (INTERIM RESULTS)}

Patricia McGloughlin and E. P. Cunningham. - The Agricultural Institute, Republic of Ireland.

The relationship between heterosis and heterozygosity was investigated for seven reproductive traits in mice. By crossing and repeated backcrossing in both directions of two unrelated strains of mice, females were produced which were $25,50,75$ and $100 \mathrm{p}$. Ioo heterozygous. Their 